\title{
Genetic Polymorphisms Associated with Environmental Exposure to Polycyclic Derivatives in African Children
}

\author{
Rodrigo Mota de Oliveira, ${ }^{1,2}$ Camylla Vilas Boas Figueiredo, ${ }^{1,2}$ Rayra Pereira Santiago, ${ }^{1,2}$ \\ Sètondji Cocou Modeste Alexandre Yahouédéhou, ${ }^{1,2}$ Suéllen Pinheiro Carvalho, ${ }^{1,2}$ \\ Silvana Souza da Paz, ${ }^{2}$ Luciana Magalhães Fiuza, ${ }^{2}$ Fernando Nunes de Miranda, \\ Caroline Conceição da Guarda, ${ }^{2}$ Cleverson Alves Fonseca, ${ }^{1}$ Milena Magalhães Aleluia, ${ }^{2}$ \\ Cynara Gomes Barbosa, ${ }^{1}$ Elisângela Vitória Adorno, ${ }^{1}$ and Marilda de Souza Gonçalves $\mathbb{D}^{1,2}$ \\ ${ }^{1}$ Laboratório de Pesquisa em Anemia (LPA), Departamento de Análises Clínicas e Toxicológicas, Faculdade de Farmácia, \\ Universidade Federal da Bahia, Rua Barão do Jeremoabo, no. 147, Ondina, 40.170-115 Salvador, BA, Brazil \\ ${ }^{2}$ Laboratório de Investigação em Genética e Hematologia Translacional (LIGHT), Instituto Gonçalo Moniz (IGM), FIOCRUZ, Rua \\ Waldemar Falcão, 121 Candeal, 40.296-710 Salvador, BA, Brazil
}

Correspondence should be addressed to Marilda de Souza Gonçalves; mari@bahia.fiocruz.br

Received 26 February 2018; Revised 29 April 2018; Accepted 17 May 2018; Published 1 August 2018

Academic Editor: Silvia Angeletti

Copyright (c) 2018 Rodrigo Mota de Oliveira et al. This is an open access article distributed under the Creative Commons Attribution License, which permits unrestricted use, distribution, and reproduction in any medium, provided the original work is properly cited.

\begin{abstract}
Background. The nonracial leukopenia may be a result of exposure to polycyclic derivatives (benzene-toluene-xylene (BTX)) and may arise from a possible change in the bone marrow microenvironment. The present study sought to evaluate the association of genetic polymorphisms in xenobiotic-metabolizing enzymes with hematological and biochemical profiles. Methods. We evaluated 89 African descendant children, exposed indirectly to benzene derivatives. Laboratory parameters were investigated by automated methods and genetic polymorphisms by PCR-RFLP and PCR multiplex. Results. Children with leukopenia had significantly decreased white blood cells (WBCs) and platelet counts, which is not consistent with benign leukopenia. In the same group, we have found that carriers of the CYP2E1 variant allele had decreased WBC and lymphocytes. Those with NQO1 variant allele had decreased WBC, neutrophil, eosinophil, monocyte, and lymphocyte counts. Carriers of the MPO variant allele had decreased WBC, neutrophil, eosinophil, basophil, monocyte, lymphocyte, and platelet counts and an elevated free iron level. Children with GSTT and GSTM null exhibited decreased WBC, neutrophil, basophil, and lymphocyte counts. Our multivariate analysis model reveals that females were independently associated with leukopenia. Conclusion. Our results suggest that the polymorphisms investigated were associated with hematological changes in the studied population. These alterations could be heightened by exposure to benzene derivatives.
\end{abstract}

\section{Introduction}

Xenobiotic compounds are classified as any foreign chemical substance inside the biological system. Most xenobiotics that the humans are exposed come from environmental pollution, food additives, cosmetics, agricultural products, toxic agents, and drugs. Usually xenobiotics are lipophilic, and if they do not undergo regular metabolism, they can be potentially harmful to exposed humans. Under physiological conditions, humans exhibit mechanisms responsible for enzymatic metabolism or biotransformation of xenobiotics. This involves the biotransformation based on phase I and phase II reactions. During the first phase, the oxidation and reduction of hydrophobic chemicals occur, while in the second phase the conjugation reactions (acetylation, methylation, and glucuronidation) take place in order to remove the byproducts from the human organism as urine or sweat $[1,2]$.

Human exposure to refining and petroleum refinery process derivatives can happen indirectly in the environment. 
These derivatives are able to promote substantial changes in human health. Polycyclic aromatic derivative causes hematological abnormalities, such as leukopenia, eosinophilia, and thrombocytopenia. The benzene-toluene-xylene fraction (BTX) changes the bone marrow microenvironment, inhibiting the hematopoiesis [3]. In addition, hematological disorders may also be related to polymorphisms in genes encoding xenobiotic-metabolizing enzymes, such as cytochrome P4502E1 (CYP2E1), myeloperoxidase (MPO), $\mathrm{NAD}(\mathrm{P}) \mathrm{H}$ :quinone oxidoreductase 1 (NQO1), and glutathione S-transferase (GST) [3-6].

The CYP2E1 is an enzyme responsible for the metabolism of xenobiotics, including toxic and therapeutic agents, and is involved in oxidative bioactivation of hydrophobic chemicals, such as benzene and acrylamide. CYP2E1 -1293G $>A /-$ $1053 C>T$ polymorphisms are associated to increased risk of developing acute myeloid leukemia (AML) and acute lymphocytic leukemia (ALL) [7, 8].

NQO1 is an enzyme involved in regulating and reducing chemical compounds that have quinone in their structure. This enzyme prevents the production of free oxygen radicals, thus protecting the cell from oxidative stress. NQO1 609C $>$ T single nucleotide polymorphism (SNP) is associated with decreased enzyme activity and an increased susceptibility to develop leukemia and bladder cancer $[9,10]$.

MPO is an oxidizing enzyme, usually restricted to myeloid cells. The enzyme is involved in the biotransformation of cigarette smoke in the highly reactive and carcinogenic benzene intermediate. This enzyme is abundant in neutrophils and monocytes and catalyzes hydrogen peroxide $\left(\mathrm{H}_{2} \mathrm{O}_{2}\right)$ to hypochlorous acid $(\mathrm{HOCl})$, a potent oxidant. The polymorphism $M P O-463 G>A$ leads to enzymatic changes, affecting the metabolism of xenobiotics, which is related to the formation of DNA adducts [3, 11-13].

GST comprises a family of 16 genes involved in six subfamilies: $\alpha$ (GSTA), $\mu$ (GSTM), $\Omega$ (GSTO), $\pi$ (GSTP), $\theta$ (GSTT), and $\zeta$ (GSTZ), and they play an important role in the cellular detoxification of chemical compounds both from endogenous and exogenous origins. GSTM1 and GSTT1 catalyze the conjugation reaction of glutathione with hydrophobic chemicals. A large deletion of the whole gene in homozygous $\left(G S T M 1^{*} 0\right.$ null alleles or GSTT1*0) results in insufficient enzyme activity, while the heterozygotes present reduced enzyme activity [14-16].

São Francisco do Conde (SFC) is a city with African origin or quilombola, a designation given to the remaining populations of quilombos, which are descendants of black slaves who preserve characteristics of the original African population [17]. In the same geographical area, an oil industry is present, which is responsible for processing and refining petroleum, which can deliver volatile organic compounds daily to the atmosphere, derived from oil [18]. In African descendant populations, ethnic-related hematological changes are present, although without clinical relevance. However, once these hematological changes are associated with environment exposure, significant characteristics may be prominent.

Thus, the aim of this study was to investigate the association of variant alleles in genes encoding xenobiotic- metabolizing enzymes, with the hematological profiles of individuals who exhibited leukopenia.

\section{Materials and Methods}

2.1. Subjects. The present cross sectional study included 89 children with median age of 9 years, aged 6-12 years, all resident in the quilombola communities located in São Francisco do Conde (SFC), Bahia, Brazil, from October 2010 to March 2011. These communities are located approximately 4.47 miles far from the oil industry.

We identified thirty-two children with leukopenia, that is, white blood cell (WBC) counts below $4.0 \times 10^{3} / \mathrm{mL}$, followed by peripheral neutropenia (neutrophils $<1.5 \times 10^{3}$ / $\mathrm{mL}$ ), whereas 57 children with normal hematological parameters were matched as control group by age and the same geographic origin.

Since all individuals were under 18 years, their legal guardians agreed to biological sample collection procedures and signed terms of informed consent were provided. The study was approved by the Research Board of the Instituto Gonçalo Moniz, Fundação Oswaldo Cruz (IGM-FIOCRUZ) and was conducted in compliance with ethical principles of the Declaration of Helsinki as well as its revision.

2.2. Socioeconomic Characteristics. The socioeconomic characteristics of the SFC population are quite contradictory, since the city has one of the largest gross domestic product and still has an elevated rate of poverty. The surveyed community has very low family income, poor basic sanitation, exposure to toxic substances, and infections. Many parents of the children we evaluated only went to elementary school, which contributes to the informal employment; hence, they have a very low purchasing power and are included in assistance programs of government in order to increase the family income.

2.3. Samples. Venous blood samples were collected by venipuncture the morning after $12 \mathrm{~h}$ of fasting in standardized conditions, at enrolment, by a specialized professional. One EDTA tube was collected to perform the hematological and genetic analysis and one tube without additives for the accomplishment of the biochemical measurement. The venous blood collection was performed in the quilombola communities of SFC, and the material was sent to the Department of Clinical Analyses and Toxicology located at Faculdade de Farmácia at Universidade Federal da Bahia (UFBA) for hematological, biochemical, and genetic analysis.

2.4. Hematological and Biochemical Data. Blood counts were performed in an automated machine (CELL-DYN Ruby, Abbott Diagnostics, Illinois, USA) at Faculdade de Farmácia at Universidade Federal da Bahia (UFBA). Biochemical analyses (uric acid, total cholesterol and fractions, creatinine, free iron, glucose, and urea) were performed on equipment COBAS INTEGRA 400 plus (Indianapolis, Indiana, USA), according to the manufacturer's instructions.

2.5. Molecular Analysis. DNA extraction was performed in peripheral blood leukocytes using DNA Kit 250 FlexiGene 
Qiagen (Hilden, North Rhine-Westphalia, Germany) in the Laboratório de Investigação em Genética e Hematologia Translacional (LIGHT) of the IGM-FIOCRUZ. Evaluation of CYP2E1 -1293G $>C /-1053 C>T$ (rs3813867/rs2031920), NQO1 609C>T (rs1800566), and MPO -463G >A (rs2333227) gene polymorphisms were performed by PCR/RFLP (polymerase chain reaction/restriction fragment length polymorphism) [10, 11, 19]. Analysis of GSTT1/GSTM1 gene polymorphisms was performed by multiplex PCR, using the $H B B$ (beta-globin) gene as an endogenous marker for the reaction [14].

2.6. Statistical Analysis. Statistical analyses were performed using the Statistical Package for the Social Sciences (SPSS) version 21.0 and GraphPad version 7.0. We considered significant $p$ values $<0.05$. Analysis of normal distribution of quantitative variables was performed using the KolmogorovSmirnov test and the independent $t$-test, and Mann-Whitney $U$ test was used for analyses of two variables comparing two groups of values within a given variable, according to the distribution of each variable. Multivariate binary logistic regression analysis was employed to assess the goodness of fit of a model designed to evaluate possible associations between leukopenia and a group of other characteristics.

\section{Results}

The baseline characteristics of the 32 leukopenic and 57 controls enrolled children including mean \pm standard deviation of laboratory parameters are shown in Table 1.

A comparison of the hematological and biochemical parameters between children with leukopenia and the control group found significantly decreased WBC and platelet counts in leukopenic children (Figure 1). No significant differences were found regarding red blood cell counts.

3.1. Association of the CYP2E1 Variant Allele c2 with Hematological and Biochemical Profiles. In order to investigate the association between CYP2E1 variant allele c2 and hematological and biochemical parameters, we selected in the leukopenic and control groups individuals with variant allele $c 2$. WBC $(p=0.004)$ and lymphocyte counts were found to be significantly decreased in children with leukopenia (Table 2).

3.2. Association of the NQO1 Variant Allele $T$ with Hematological and Biochemical Profiles. The association of NQO1 variant allele T with hematological and biochemical characteristics was also investigated. Among children with leukopenia, we found decreased WBC $(p=0.0001)$, neutrophils $(p=0.0001)$, eosinophils $(p=0.005)$, monocytes $(p=0.002)$, and lymphocytes $(p=0.0001)$ (Table 2$)$.

3.3. Association of the MPO Variant Allele A with Hematological and Biochemical Profiles. Children with leukopenia carriers of the variant allele A for MPO gene polymorphism also had significantly decreased WBC $(p=$ $0.0001)$, neutrophils $(p=0.0001)$, eosinophils $(p=0.032)$, basophils $(p=0.002)$, monocytes $(p=0.0007)$, lymphocytes
TABLE 1: Comparison of hematological characteristics between leukopenic and control children.

\begin{tabular}{lcc}
\hline Hematological parameters & $\begin{array}{c}\text { Leukopenic (32) } \\
\text { Mean } \pm \text { SD }\end{array}$ & $\begin{array}{c}\text { Controls (57) } \\
\text { Mean } \pm \text { SD }\end{array}$ \\
\hline RBC $\left(\times 10^{6} / \mathrm{mL}\right)$ & $4.69 \pm 0.32$ & $4.67 \pm 0.32$ \\
Hemoglobin $(\mathrm{g} / \mathrm{dL})$ & $13.19 \pm 0.83$ & $12.92 \pm 0.83$ \\
Hematocrit $(\%)$ & $39.45 \pm 2.55$ & $38.73 \pm 2.55$ \\
MCV & $84.15 \pm 3.57$ & $83.14 \pm 3.57$ \\
MCH & $28.02 \pm 1.65$ & $27.75 \pm 1.65$ \\
CHCM & $33.29 \pm 1.22$ & $33.36 \pm 1.22$ \\
RDW $(\%)$ & $14.65 \pm 0.97$ & $14.87 \pm 0.97$ \\
WBC $\left(\times 10^{3} / \mathrm{mL}\right)$ & $3.51 \pm 0.66$ & $7.06 \pm 0.66$ \\
Neutrophils $\left(\times 10^{3} / \mathrm{mL}\right)$ & $1.13 \pm 0.34$ & $3.08 \pm 0.34$ \\
Eosinophils $\left(\times 10^{3} / \mathrm{mL}\right)$ & $0.23 \pm 0.15$ & $0.52 \pm 0.15$ \\
Basophils $\left(\times 10^{3} / \mathrm{mL}\right)$ & $0.05 \pm 0.03$ & $0.08 \pm 0.03$ \\
Lymphocytes $\left(\times 10^{3} / \mathrm{mL}\right)$ & $1.80 \pm 0.38$ & $2.88 \pm 0.38$ \\
Monocytes $\left(\times 10^{3} / \mathrm{mL}\right)$ & $0.31 \pm 0.08$ & $0.49 \pm 0.08$ \\
Platelets $\left(\times 10^{3} / \mathrm{mL}\right)$ & $250.93 \pm 59.02$ & $303.87 \pm 59.02$ \\
\hline
\end{tabular}

SD: standard deviation; RBC: red blood cell; MCV: mean corpuscular volume; $\mathrm{MCH}$ : mean corpuscular hemoglobin; MCHC: mean corpuscular hemoglobin concentration; RDW: red cell distribution width; WBC: white blood cell; HDL-c: high-density lipoproteins of cholesterol; LDL-c: lowdensity lipoproteins of cholesterol.

$(p=0.0001)$, and platelets $(p=0.004)$; in addition, we also found an elevated free iron level $(p=0.018)$ (Table 3$)$.

3.4. Association of the GSTT1 Null with Hematological and Biochemical Profiles. The association of GSTT1 null gene polymorphism was also tested among children with leukopenia. We found significantly decreased WBC $(p=0.0021)$, neutrophil $(p=0.0001)$, basophil $(p=0.002)$, and lymphocyte $(p=0.014)$ counts (Table 4$)$.

3.5. Association of the GSTM1 Null with Hematological and Biochemical Profiles. A comparison of GSTM1 null gene polymorphism in the group of children with leukopenia also found to be significantly decreased WBC $(p=0.0001)$, neutrophil $(p=0.0001)$, basophil $(p=0.0449)$, lymphocyte $(p=$ $0.0001)$, and monocyte $(p=0.0014)$ counts (Table 4$)$.

3.6. Multivariate Analysis Model. Our three multivariate analysis model $(p=0.049, p=0.037$, and $p=0.048)$ were designed to investigate any associations between polymorphisms, age, and sex with leukopenia (Table 5). From all the variables employed in the models, we found that females were independently associated with leukopenia.

\section{Discussion}

The decrease in the WBC counts verified herein in the leukopenic group may be related to racial variation as well as the presence of an underlying pathology. However, in the racial variation, also named benign leukopenia, the neutrophil count is never as low as $1.5 \times 10^{3} / \mathrm{mL}$. Individuals with racial neutropenia do not exhibit significant changes in WBC counts, and variations in cell morphology may be present 


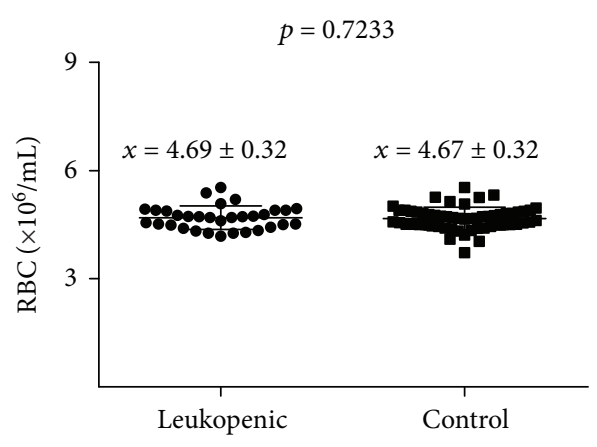

(a)

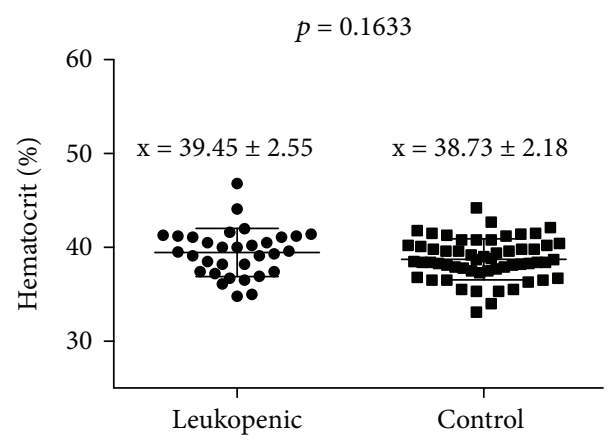

(c)

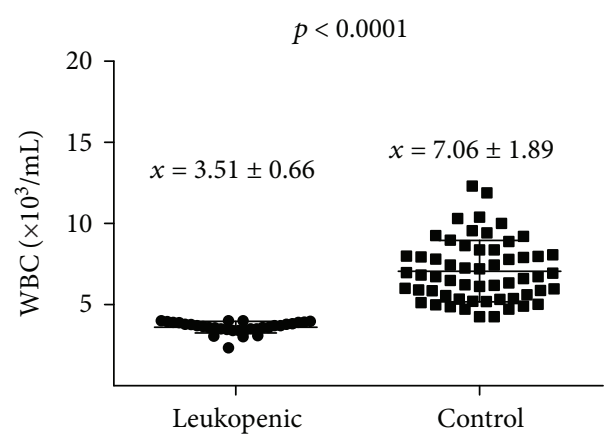

(e)

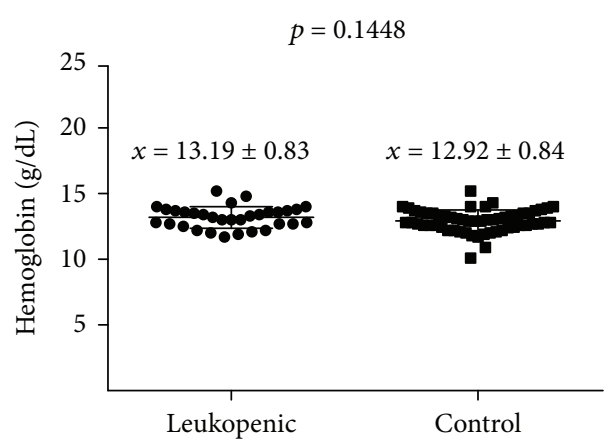

(b)

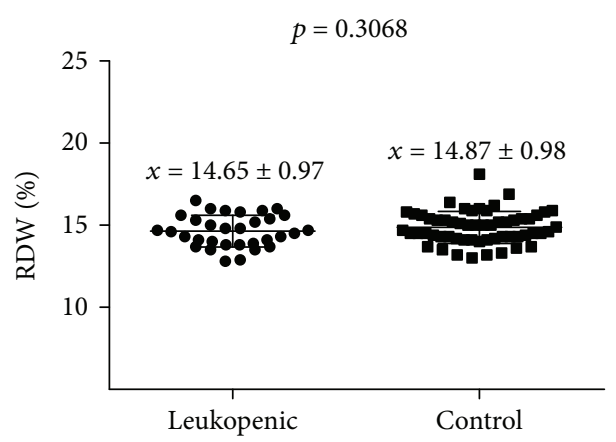

(d)

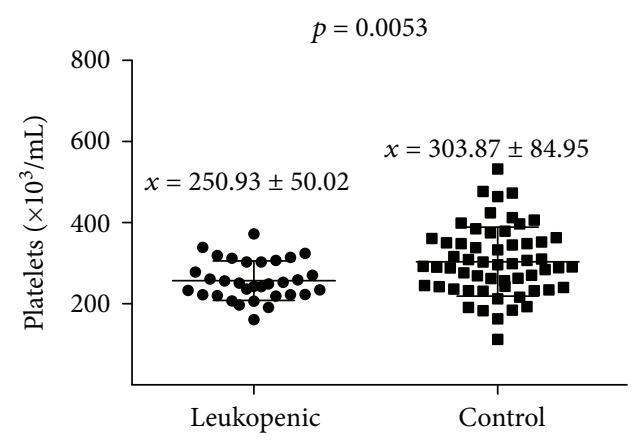

(f)

FIGURE 1: Comparison of hematological parameters between leukopenic group and controls ((a) RBC; (b) hemoglobin; (c) hematocrit; (d) RDW; (e) WBC, and (f) platelets).

[20-22]. To date, no data was published regarding the association between ethnicity and decreased platelet counts, as observed in our group of children who had leukopenia. Thus, we hypothesized that the leukopenia that children exhibited was not a benign leukopenia and may be increased by the environmental exposure to petroleum derivatives.

The BTX fraction of petroleum alters the bone marrow microenvironment, inhibiting hematopoiesis. Neutropenia associated with the toxicity of chemicals is related to polycyclic aromatic part of benzene derivatives. Decreased WBC counts followed by neutropenia correspond to the main hematologic effect of benzene secondary to hypoplasia and, less frequently, only thrombocytopenia or associated with neutropenia [5, 23]. Decreased counts of WBC, neutrophils, lymphocytes, and monocytes were found in the recent study designed to evaluate the hematotoxicity of low-level benzene exposure among workers from a petrochemical factory
[24]. Similarly, in an evaluation among pesticide retailers, the results of hematological assessment showed that monocyte counts, hemoglobin, hematocrit, mean corpuscular volume, mean corpuscular hemoglobin, and platelet distribution width levels were also significantly lower [25]. Altogether, these results suggest that occupational exposure may be responsible for the hematological changes exhibited by the workers.

The toxic effect of benzoquinone occurs due to the formation of DNA adducts and the production of reactive oxygen species (ROS). The benzene toxicity affects the bone marrow stroma cells, which hinders the production of physiological levels of cytokines which are responsible for maintaining both growth and development of hematopoietic cells. Exposure to benzene and its derivatives may promote a decrease in hemoglobin concentrations, red blood cell (RBC) counts, WBC counts, and progenitor cells. The absorption of 
TABLE 2: Association of hematological parameters with variant allele of CYP2E1 -1293G>C/-1053C $>T$ and NQO1 609C $>T$ polymorphisms in both leukopenic and control children.

\begin{tabular}{|c|c|c|c|c|c|c|}
\hline \multirow[b]{2}{*}{ Hematological parameters } & \multicolumn{3}{|c|}{ Presence of the CYP2E1 variant allele c2 } & \multicolumn{3}{|c|}{ Presence of the NQO1 variant allele $\mathrm{T}$} \\
\hline & $\begin{array}{l}\text { Leukopenic (3) } \\
\text { Mean } \pm \text { SD }\end{array}$ & $\begin{array}{l}\text { Controls (6) } \\
\text { Mean } \pm \text { SD }\end{array}$ & $p$ & $\begin{array}{c}\text { Leukopenic (17) } \\
\text { Mean } \pm \text { SD }\end{array}$ & $\begin{array}{c}\text { Controls (26) } \\
\text { Mean } \pm \text { SD }\end{array}$ & $p$ \\
\hline $\mathrm{RBC}\left(\times 10^{6} / \mathrm{mL}\right)$ & $4.56 \pm 0.09$ & $4.59 \pm 0.07$ & 0.7843 & $4.67 \pm 0.09$ & $4.57 \pm 0.07$ & 0.3092 \\
\hline Hemoglobin (g/dL) & $13.10 \pm 0.26$ & $13.25 \pm 0.19$ & 0.6663 & $13.31 \pm 0.19$ & $12.82 \pm 0.19$ & 0.0848 \\
\hline Hematocrit (\%) & $39.13 \pm 1.13$ & $39.33 \pm 0.25$ & 0.8151 & $39.71 \pm 0.65$ & $38.43 \pm 0.51$ & 0.1268 \\
\hline RDW (\%) & $14.60 \pm 0.90$ & $14.37 \pm 0.28$ & 0.7559 & $14.73 \pm 0.24$ & $14.86 \pm 0.19$ & 0.6736 \\
\hline WBC $\left(\times 10^{3} / \mathrm{mL}\right)$ & $3.45 \pm 0.20$ & $8.23 \pm 1.43$ & 0.0449 & $3.58 \pm 0.10$ & $6.58 \pm 0.25$ & $<0.0001$ \\
\hline Neutrophils $\left(\times 10^{3} / \mathrm{mL}\right)$ & $1.04 \pm 0.22$ & $4.10 \pm 0.96$ & 0.0671 & $1.13 \pm 0.06$ & $2.79 \pm 0.19$ & $<0.0001$ \\
\hline Eosinophils $\left(\times 10^{3} / \mathrm{mL}\right)$ & $0.17 \pm 0.05$ & $0.54 \pm 0.11$ & 0.0655 & $0.23 \pm 0.03$ & $0.43 \pm 0.05$ & 0.0059 \\
\hline Basophils $\left(\times 10^{3} / \mathrm{mL}\right)$ & $0.04 \pm 0.02$ & $0.08 \pm 0.01$ & 0.2062 & $0.06 \pm 0.007$ & $0.07 \pm 0.004$ & 0.1333 \\
\hline Lymphocytes $\left(\times 10^{3} / \mathrm{mL}\right)$ & $1.91 \pm 0.08$ & $2.92 \pm 0.28$ & 0.0461 & $1.83 \pm 0.06$ & $2.85 \pm 0.15$ & $<0.0001$ \\
\hline Monocytes $\left(\times 10^{3} / \mathrm{mL}\right)$ & $0.28 \pm 0.01$ & $0.59 \pm 0.11$ & 0.0944 & $0.33 \pm 0.02$ & $0.42 \pm 0.02$ & 0.0024 \\
\hline Platelets $\left(\times 10^{3} / \mathrm{mL}\right)$ & $233.67 \pm 15.34$ & $299.83 \pm 38.24$ & 0.2828 & $263.76 \pm 11.62$ & $304.96 \pm 16.96$ & 0.0811 \\
\hline Uric acid (mg/dL) & $3.267 \pm 1.007$ & $4.133 \pm 0.5989$ & 0.1667 & $3.92 \pm 0.99$ & $4.31 \pm 0.73$ & 0.1194 \\
\hline Total cholesterol (mg/dL) & $169.7 \pm 17.62$ & $204.5 \pm 82.21$ & 0.6190 & $172.6 \pm 40.27$ & $166.00 \pm 34.64$ & 0.4639 \\
\hline HDL-c (mg/dL) & $39.00 \pm 3.606$ & $40.67 \pm 7.528$ & $>0.9999$ & $41.35 \pm 10.85$ & $42.38 \pm 10.17$ & 0.6443 \\
\hline $\mathrm{LDL}-\mathrm{c}(\mathrm{mg} / \mathrm{dL})$ & $111.8 \pm 20.44$ & $146.1 \pm 75.91$ & 0.6190 & $113.30 \pm 31.73$ & $108.40 \pm 30.32$ & 0.5345 \\
\hline Triglycerides (mg/dL) & $94.33 \pm 77.73$ & $88.83 \pm 48.80$ & 0.7619 & $89.88 \pm 49.42$ & $76.08 \pm 30.14$ & 0.5588 \\
\hline Creatinine (mg/dL) & $0.5167 \pm 0.1305$ & $0.6000 \pm 0.1161$ & 0.5000 & $0.76 \pm 0.28$ & $0.70 \pm 0.176$ & 0.9265 \\
\hline Free iron (mg/dL) & $91.00 \pm 22.61$ & $80.33 \pm 18.70$ & 0.5476 & $98.82 \pm 37.05$ & $83.85 \pm 36.84$ & 0.1965 \\
\hline Glucose (mg/dL) & $97.00 \pm 9.539$ & $100.7 \pm 9.092$ & 0.7619 & $91.24 \pm 11.13$ & $97.69 \pm 9.35$ & 0.0805 \\
\hline Urea (mg/dL) & $29.67 \pm 10.07$ & $22.00 \pm 6.870$ & 0.4286 & $23.71 \pm 7.69$ & $22.42 \pm 6.78$ & 0.7629 \\
\hline
\end{tabular}

SD: standard deviation; RBC: red blood cell; RDW: red cell distribution width; WBC: white blood cell; HDL-c: high-density lipoproteins of cholesterol; LDL-c: low-density lipoproteins of cholesterol.

the toluene fraction has been associated with bone marrow damage and impaired hematopoiesis, as observed in animal models; however, more studies are needed to clarify the underlying mechanism $[5,23,26]$. A description of two cases has also verified complex chromosomal rearrangements and lower natural killer (NK) cells in female Brazilian gas station workers who presented benzene poisoning symptoms and miscarriage history [27].

Carrier individuals of the variant allele of CYP2E1 $-1293 G>C /-1053 C>T$ (rs3813867/rs2031920) who are also exposed to polycyclic aromatic derivatives may have a high CYP2E1 activity and are prone to develop hematological malignancies, such as AML and ALL. The presence of the variant allele of these SNPs alters enzymatic activity, affecting the metabolism pathway; hence, the elimination of toxic substances from the human body is also impaired. Herein, the presence of the variant allele of CYP2E1 $-1293 G>C /-1053 C>T$ (rs3813867/rs2031920) was associated with decreased WBC counts. This effect may be explained by the population ethnic origin, which is also heightened by the exposure to chemicals, which affect the production of the blood cells [8]. The evaluation of variant allele of CYP2E1 in sickle cell anemia patients also suggested an association with hematological changes [28].

In this study, we observed that WBC counts were reduced in carrier children of the variant allele in NQO1 609C>T (rs1800566). Studies suggest that the polymorphism in NQO1 609C > T (rs1800566) is related to toxicity of benzene, and this, in turn, is associated with damage in the bone marrow, since its metabolites are topoisomerase II inhibitors. Carrier individuals of the variant allele in NQO1 609C $>$ T (rs1800566) that have a null or reduced activity of the enzyme have increased risk for leukemia. The NQO1 enzyme is involved in the metabolism of xenobiotics, which confers protection against cancers, since this enzyme can stabilize $p 53$ and, thus, assists the apoptosis, as well as the clonal expansion of malignant cells. The decreased or null NQO1 activity is due to polymorphisms which reduce or eliminate these benefits and thus contributes to the incidence of cancer $[29,30]$.

In the present study, we observed that the $M P O$ $-463 G>A$ (rs2333227) SNP was significantly associated in the leukopenic group to decreased $\mathrm{WBC}$ and platelet counts. The $M P O-463 G>A$ (rs2333227) polymorphism may result in a decreased enzyme activity and even greater association with AML, since homozygotes for the G allele correspond to $80 \%$ of cases of acute promyelocytic leukemia. We also found that the presence of the variant allele in the $M P O-463 G>A$ (rs2333227) was associated with increased free iron levels in the leukopenic group, which may be related with increased oxidative stress, whereas transition metals may donate or accept electrons during 
TABLE 3: Association of hematological parameters with variant allele of polymorphisms in $M P O-463 G>A$ in both leukopenic and control children.

\begin{tabular}{|c|c|c|c|}
\hline \multirow[b]{2}{*}{ Hematological parameters } & \multicolumn{2}{|c|}{ Presence of the $M P O$ variant allele $\mathrm{A}$} & \multirow[b]{2}{*}{$p$} \\
\hline & $\begin{array}{c}\text { Leukopenic (17) } \\
\text { Mean } \pm \text { SD }\end{array}$ & $\begin{array}{c}\text { Controls (34) } \\
\text { Mean } \pm \text { SD }\end{array}$ & \\
\hline $\mathrm{RBC}\left(\times 10^{6} / \mathrm{mL}\right)$ & $4.67 \pm 0.07$ & $4.70 \pm 0.04$ & 0.721 \\
\hline Hemoglobin (g/dL) & $13.17 \pm 0.21$ & $12.96 \pm 0.11$ & 0.344 \\
\hline Hematocrit (\%) & $39.36 \pm 0.57$ & $38.76 \pm 0.33$ & 0.335 \\
\hline RDW (\%) & $14.81 \pm 0.23$ & $14.95 \pm 0.15$ & 0.617 \\
\hline $\mathrm{WBC}\left(\times 10^{3} / \mathrm{mL}\right)$ & $3.69 \pm 0.07$ & $6.96 \pm 0.28$ & $<0.0001$ \\
\hline Neutrophils $\left(\times 10^{3} / \mathrm{mL}\right)$ & $1.17 \pm 0.07$ & $3.03 \pm 0.21$ & $<0.0001$ \\
\hline Eosinophils $\left(\times 10^{3} / \mathrm{mL}\right)$ & $0.27 \pm 0.04$ & $0.50 \pm 0.07$ & 0.032 \\
\hline Basophils $\left(\times 10^{3} / \mathrm{mL}\right)$ & $0.05 \pm 0.007$ & $0.08 \pm 0.005$ & 0.002 \\
\hline Lymphocytes $\left(\times 10^{3} / \mathrm{mL}\right)$ & $1.87 \pm 0.06$ & $2.86 \pm 0.12$ & $<0.0001$ \\
\hline Monocytes $\left(\times 10^{3} / \mathrm{mL}\right)$ & $0.34 \pm 0.02$ & $0.48 \pm 0.02$ & 0.0007 \\
\hline Platelets $\left(\times 10^{3} / \mathrm{mL}\right)$ & $247.18 \pm 11.12$ & $318.56 \pm 15.55$ & 0.004 \\
\hline Uric acid (mg/dL) & $4.035 \pm 1.001$ & $4.282 \pm 0.7505$ & 0.3275 \\
\hline Total cholesterol (mg/dL) & $158.6 \pm 34.21$ & $178.0 \pm 44.54$ & 0.3642 \\
\hline HDL-c (mg/dL) & $39.94 \pm 11.66$ & $43.29 \pm 8.476$ & 0.1023 \\
\hline LDL-c (mg/dL) & $103.1 \pm 28.83$ & $119.5 \pm 41.59$ & 0.4913 \\
\hline Triglycerides $(\mathrm{mg} / \mathrm{dL})$ & $78.12 \pm 42.23$ & $76.15 \pm 31.95$ & 0.6958 \\
\hline Creatinine (mg/dL) & $0.7853 \pm 0.354$ & $0.6503 \pm 0.177$ & 0.1614 \\
\hline Free iron (mg/dL) & $107.6 \pm 37.59$ & $87.15 \pm 38.22$ & 0.018 \\
\hline Glucose (mg/dL) & $94.76 \pm 9.291$ & $96.97 \pm 9.233$ & 0.3229 \\
\hline Urea (mg/dL) & $23.12 \pm 6.790$ & $23.15 \pm 6.378$ & 0.7776 \\
\hline
\end{tabular}

SD: standard deviation; RBC: red blood cell; RDW: red cell distribution width; WBC: white blood cell; HDL-c: high-density lipoproteins of cholesterol; LDL-c: low-density lipoproteins of cholesterol.

intracellular responses by promoting production of free radicals [29, 31, 32].

Deletions in GSTM1 and GSTT1 genes are associated with reduced or null enzyme activity. Studies have shown that there is an association between the decreased enzyme activity and the susceptibility to develop several types of cancer, such as oral, gastric, and bladder cancer, as well as chronic myeloid leukemia (CML) in different ethnic groups worldwide [33, 34]. The WBC and neutrophil counts were decreased in the leukopenic group. This finding may be suggestive of hematological disorders of the bone marrow microenvironment in these children, leading to a possible peripheral pancytopenia, increased by the exposure to benzene derivatives. The presence of the GSTM1 null genotype may increase the risk to develop AML, as observed in an East Asian population, while the total deletion in GSTT1 increases the risk of AML in Asian Caucasians. The double deletion in these genes confers a risk of 5.92 times greater to the development of leukopenia in the Brazilian population, which may progress to pancytopenia or cell aplasia $[14,35]$.

Our multivariate analysis shows that female gender and age (older than 9 years) are suggestive as protective factors for the development of leukopenia, even with the polymorphisms in NQO1 $609 \mathrm{C}>\mathrm{T}$ or GSTM1. However, when we evaluate NQO1 609C>T and GSTM1 gene polymorphisms, the occurrence of leukopenia is favored (model 3, Table 5). This can be explained by the fact that male children younger than 9 years old follow their mothers at work, since many women are responsible for the financial support of the home, through fishing in the geographical region of SFC.

The present study allowed us to identify the hematological profile of individuals with leukopenia and associate these parameters with polymorphisms in genes encoding xenobiotic-metabolizing enzymes. However, our study design does not allow the long-term follow-up of individuals exposed to petroleum derivatives to determine whether these hematological changes will eventually lead to the development of a malignant disease. Still, it is important to highlight that the genetic sensitivity to the environment exposure is a complex association and a constant hematological evaluation is useful to monitor this possible outcome.

\section{Conclusion}

This study showed that $M P O-463 G>A$ (rs2333227), CYP2E1 $-1293 G>C /-1053 C>T($ rs3813867/rs2031920), NQO1 609C $>T$ (rs1800566), GSTT1, and GSTM1 gene polymorphisms are associated with hematological alterations. This population, specifically, may have these biomarkers enhanced through 
TABLE 4: Association of hematological parameters with variant allele of polymorphisms in GSTT1 and GSTM1 in both leukopenic and control children.

\begin{tabular}{|c|c|c|c|c|c|c|}
\hline \multirow[b]{2}{*}{ Hematological parameters } & \multicolumn{3}{|c|}{ GSTT1 null } & \multicolumn{3}{|c|}{ GSTM1 null } \\
\hline & $\begin{array}{l}\text { Leukopenic (4) } \\
\text { Mean } \pm \text { SD }\end{array}$ & $\begin{array}{c}\text { Controls (15) } \\
\text { Mean } \pm \text { SD }\end{array}$ & $p$ & $\begin{array}{l}\text { Leukopenic (11) } \\
\text { Mean } \pm \text { SD }\end{array}$ & $\begin{array}{c}\text { Controls (20) } \\
\text { Mean } \pm \text { SD }\end{array}$ & $p$ \\
\hline $\mathrm{RBC}\left(\times 10^{6} / \mathrm{mL}\right)$ & $4.53 \pm 0.13$ & $4.79 \pm 0.08$ & 0.1410 & $4.70 \pm 0.09$ & $4.65 \pm 0.08$ & 0.7101 \\
\hline Hemoglobin (g/dL) & $12.88 \pm 0.43$ & $13.12 \pm 0.20$ & 0.5956 & $13.20 \pm 0.14$ & $12.83 \pm 0.18$ & 0.1791 \\
\hline Hematocrit (\%) & $38.38 \pm 1.16$ & $39.08 \pm 0.61$ & 0.6032 & $39.53 \pm 0.48$ & $38.21 \pm 0.54$ & 0.1152 \\
\hline RDW (\%) & $14.30 \pm 0.77$ & $15.25 \pm 0.24$ & 0.1337 & $14.75 \pm 0.33$ & $14.75 \pm 0.19$ & 0.9898 \\
\hline WBC $\left(\times 10^{3} / \mathrm{mL}\right)$ & $3.70 \pm 0.12$ & $7.42 \pm 0.52$ & 0.0021 & $3.69 \pm 0.06$ & $7.11 \pm 0.39$ & $<0.0001$ \\
\hline Neutrophils $\left(\times 10^{3} / \mathrm{mL}\right)$ & $1.17 \pm 0.07$ & $3.22 \pm 0.34$ & 0.0081 & $1.27 \pm 0.09$ & $3.34 \pm 0.33$ & $<0.0001$ \\
\hline Eosinophils $\left(\times 10^{3} / \mathrm{mL}\right)$ & $0.23 \pm 0.08$ & $0.64 \pm 0.14$ & 0.1556 & $0.21 \pm 0.04$ & $0.42 \pm 0.08$ & 0.0618 \\
\hline Basophils $\left(\times 10^{3} / \mathrm{mL}\right)$ & $0.03 \pm 0.01$ & $0.10 \pm 0.008$ & 0.0027 & $0.05 \pm 0.01$ & $0.08 \pm 0.007$ & 0.0449 \\
\hline Lymphocytes $\left(\times 10^{3} / \mathrm{mL}\right)$ & $1.90 \pm 0.09$ & $2.93 \pm 0.19$ & 0.0142 & $1.84 \pm 0.09$ & $2.79 \pm 0.14$ & $<0.0001$ \\
\hline Monocytes $\left(\times 10^{3} / \mathrm{mL}\right)$ & $0.37 \pm 0.06$ & $0.52 \pm 0.05$ & 0.1789 & $0.33 \pm 0.02$ & $0.48 \pm 0.03$ & 0.0014 \\
\hline Platelets $\left(\times 10^{3} / \mathrm{mL}\right)$ & $264.75 \pm 18.75$ & $279.67 \pm 13.98$ & 0.6141 & $287.45 \pm 16.97$ & $271.27 \pm 12.10$ & 0.5175 \\
\hline Uric acid (mg/dL) & $4.45 \pm 0.99$ & $4.02 \pm 0.65$ & 0.5139 & $4.39 \pm 0.91$ & $4.25 \pm 0.84$ & 0.7525 \\
\hline Total cholesterol (mg/dL) & $152.30 \pm 42.53$ & $172.10 \pm 31.22$ & 0.9801 & $180.40 \pm 43.91$ & $164.80 \pm 34.72$ & 0.0967 \\
\hline HDL-c (mg/dL) & $39.25 \pm 7.14$ & $43.60 \pm 6.30$ & 0.2131 & $41.09 \pm 10.35$ & $44.30 \pm 9.75$ & 0.4323 \\
\hline LDL-c (mg/dL) & $101.10 \pm 37.82$ & $114.90 \pm 31.31$ & 0.8989 & $119.20 \pm 34.15$ & $106.20 \pm 29.32$ & 0.1202 \\
\hline Triglycerides (mg/dL) & $59.75 \pm 19.52$ & $68.33 \pm 22.67$ & 0.7500 & $100.40 \pm 52.68$ & $71.45 \pm 37.12$ & 0.0927 \\
\hline Creatinine (mg/dL) & $0.65 \pm 0.22$ & $0.65 \pm 0.16$ & 0.9900 & $0.79 \pm 0.35$ & $0.61 \pm 0.16$ & 0.1790 \\
\hline Free iron (mg/dL) & $88.75 \pm 41.77$ & $71.07 \pm 22.19$ & 0.3965 & $85.45 \pm 41.90$ & $86.20 \pm 33.66$ & 0.7069 \\
\hline Glucose (mg/dL) & $93.25 \pm 10.28$ & $96.27 \pm 6.47$ & 0.5175 & $90.73 \pm 9.56$ & $97.50 \pm 8.49$ & 0.0882 \\
\hline Urea (mg/dL) & $22.75 \pm 4.11$ & $24.47 \pm 6.59$ & 0.6068 & $24.73 \pm 8.41$ & $22.35 \pm 4.52$ & 0.7516 \\
\hline
\end{tabular}

SD: standard deviation; RBC: red blood cell; RDW: red cell distribution width; WBC: white blood cell; HDL-c: high-density lipoproteins of cholesterol; LDL-c: low-density lipoproteins of cholesterol.

TABLE 5: Multivariate analysis associating gene polymorphisms related to xenobiotic metabolism among children with leukopenia.

\begin{tabular}{lccccc}
\hline Variables & $B$ & SD & $t$ & $p$ & $p$ of model \\
\hline Model 1 & & & & & \\
$\quad$ Female & -0.444 & 0.178 & -2.499 & 0.019 & \\
$\quad$ Age & -0.193 & 0.168 & -1.153 & 0.258 & 0.049 \\
$\quad$ NQO1 609C>T & 0.208 & 0.165 & 1.260 & 0.218 & \\
Model 2 & & & & & \\
$\quad$ Female & -0.536 & 0.189 & -2.842 & 0.008 & \\
Age & -0.207 & 0.166 & -1.243 & 0.224 & 0.037 \\
GSTM1 & -0.273 & 0.184 & 1.480 & 0.150 & \\
Model 3 & & & & & \\
Female & -0.537 & 0.188 & -2.859 & 0.008 & \\
Age & -0.208 & 0.165 & -1.255 & 0.220 & \\
GSTM1 & 0.252 & 0.185 & 1.363 & 0.184 & 0.048 \\
NQO1 609C>T & 0.185 & 0.163 & 1.132 & 0.267 & \\
\hline & & & & & \\
\hline
\end{tabular}

the exposure to polycyclic aromatic derivatives, since there was also a reduction in neutrophil and platelet counts.

\section{Conflicts of Interest}

The authors declare no conflict of interest.

\section{Acknowledgments}

This study was supported by the Fundação de Amparo à Pesquisa do Estado da Bahia under Grant no. PET0018/2010.

\section{References}

[1] M. Krajinovic, H. Sinnett, C. Richer, D. Labuda, and D. Sinnett, "Role of NQO1, MPO and CYP2E1 genetic polymorphisms in the susceptibility to childhood acute lymphoblastic leukemia," International Journal of Cancer, vol. 97, no. 2, pp. 230-236, 2002.

[2] M. Taspinar, S. E. Aydos, O. Comez, A. H. Elhan, H. G. Karabulut, and A. Sunguroglu, "CYP1A1, GST gene polymorphisms and risk of chronic myeloid leukemia," Swiss Medical Weekly, vol. 138, no. 1-2, pp. 12-17, 01.

[3] L. Zhang, N. Rothman, G. Li et al., "Aberrations in chromosomes associated with lymphoma and therapy-related leukemia in benzene-exposed workers," Environmental and Molecular Mutagenesis, vol. 48, no. 6, pp. 467-474, 2007.

[4] M. Aksoy, K. Dincol, T. Akgun, S. Erdem, and G. Dincol, "Haematological effects of chronic benzene poisoning in 217 workers," Occupational and Environmental Medicine, vol. 28, no. 3, pp. 296-302, 1971.

[5] L. Haro-García, N. Vélez-Zamora, G. Aguilar-Madrid et al., "Alteraciones hematológicas en trabajadores expuestos ocupacionalmente a mezcla de benceno-tolueno-Xileno 
(BTX) en una fábrica de pinturas," Revista Peruana de Medicina Experimental y Salud Pública, vol. 29, no. 2, pp. 181-187, 2012.

[6] G. M. Moreira and S. F. Gomes, "Intoxicação ocupacional pelo benzeno: um assunto de saúde ambiental," Revistas, vol. 68, no. 2, p. 171, 2012.

[7] B. I. Ghanayem and U. Hoffler, "Investigation of xenobiotics metabolism, genotoxicity, and carcinogenicity using Cyp2e1(-/-) mice," Current Drug Metabolism, vol. 8, no. 7, pp. 728-749, 2007.

[8] R. Kanagal-Shamanna, W. Zhao, S. Vadhan-Raj et al., "Overexpression of CYP2E1 mRNA and protein: implications of xenobiotic induced damage in patients with de novo acute myeloid leukemia with inv(16)(p13.1q22); CBF $3-\mathrm{MYH11,"}$ International Journal of Environmental Research and Public Health, vol. 9, no. 8, pp. 2788-2800, 2012.

[9] E. K. Choi, K. Terai, I. M. Ji et al., "Upregulation of $\mathrm{NAD}(\mathrm{P}) \mathrm{H}$ :quinone oxidoreductase by radiation potentiates the effect of bioreductive beta-lapachone on cancer cells," Neoplasia, vol. 9, no. 8, pp. 634-642, 2007.

[10] X. Guo, Y. Zeng, H. Deng et al., "Genetic polymorphisms of CYP2E1, GSTP1, NQO1 and MPO and the risk of nasopharyngeal carcinoma in a Han Chinese population of Southern China," BMC Research Notes, vol. 3, no. 1, p. 212, 2010.

[11] A. Bag, N. Bag, L. M. Jeena, and N. S. Jyala, "Glutathione Stransferase T1 and myeloperoxidase $-463 \mathrm{G}>\mathrm{A}$ genotypes in lung cancer patients of Kumaun region," Journal of Natural Science, Biology and Medicine, vol. 5, no. 2, pp. 293-296, 2014.

[12] A. Etemadi, F. Islami, D. H. Phillips et al., "Variation in PAHrelated DNA adduct levels among non-smokers: the role of multiple genetic polymorphisms and nucleotide excision repair phenotype," International Journal of Cancer, vol. 132, no. 12, pp. 2738-2747, 2013.

[13] M. C. Perianayagam, H. Tighiouart, O. Liangos et al., "Polymorphisms in the myeloperoxidase gene locus are associated with acute kidney injury-related outcomes," Kidney International, vol. 82, no. 8, pp. 909-919, 2012.

[14] M. S. Goncalves, J. P. Moura Neto, C. L. Souza, P. Melo, and M. G. Reis, "Evaluating glutathione S-transferase (GST) null genotypes (GSTT1 and GSTM1) as a potential biomarker of predisposition for developing leukopenia," International Journal of Laboratory Hematology, vol. 32, no. 1p1, pp. e49e56, 2010.

[15] N. Marinkovic, D. Pasalic, and S. Potocki, "Polymorphisms of genes involved in polycyclic aromatic hydrocarbons' biotransformation and atherosclerosis," Biochemia Medica, vol. 23, no. 3, pp. 255-265, 2013.

[16] P. Sherratt and J. Hayes, Glutathione S-Transferases in Enzyme Systems that Metabolise Drugs and Other Xenobiotics Ioannides C, John Wiley and Sons Ltd UK, 2001.

[17] R. P. Santiago, R. M. Oliveira, L. F. Soares et al., "Hemoglobin variant profiles among Brazilian quilombola communities," Hemoglobin, vol. 41, no. 2, pp. 83-88, 2017.

[18] R. S. C. de Rezende, Análise das emissões atmosféricas no setor de refino de petróleo. Undergraduate thesis, Universidade de São Paulo, Lorena, SP, Brazil, 2013.

[19] A. S. Sameer, S. Nissar, Q. Qadri, S. Alam, S. M. Baba, and M. A. Siddiqi, "Role of CYP2E1 genotypes in susceptibility to colorectal cancer in the Kashmiri population," Human Genomics, vol. 5, no. 6, pp. 530-537, 2011.
[20] T. F. Lorenzi, Manual de hematologia: propedêutica e clínica, Guanabara Koogan, Rio de Janeiro, Brazil, 2003.

[21] Z. Paz, M. Nails, and E. Ziv, "The genetics of benign neutropenia," The Israel Medical Association Journal, vol. 13, no. 10, pp. 625-629, 2011.

[22] Y. Shoenfeld, O. Ben-Tal, S. Berliner, and J. Pinkhas, "The outcome of bacterial infection in subjects with benign familial leukopenia (BFL)," Biomedicine \& Pharmacotherapy = Biomedecine \& Pharmacotherapie, vol. 39, no. 1, pp. 23-26, 1985.

[23] J. Chen, "Animal models for acquired bone marrow failure syndromes," Clinical Medicine \& Research, vol. 3, no. 2, pp. 102-108, 2005.

[24] J. Li, X. Xing, X. Zhang et al., "Enhanced H3K4me3 modifications are involved in the transactivation of DNA damage responsive genes in workers exposed to low-level benzene," Environmental Pollution, vol. 234, pp. 127-135, 2018.

[25] M. Neghab, H. Jalilian, S. Taheri, M. Tatar, and Z. H. Zadeh, "Evaluation of hematological and biochemical parameters of pesticide retailers following occupational exposure to a mixture of pesticides," Life Sciences, vol. 202, pp. 182-187, 2018.

[26] M. Mumtaz and J. George, Toxicological Profile for Polycyclic Aromatic Hydrocarbons (PAHs), US Department of Health and Human Services, Agency for Toxic Substances and Disease Registry, Atlanta, GA, USA, 1995.

[27] F. Santiago, S. Lima, T. Pinheiro et al., "Benzene poisoning, clinical and blood abnormalities in two Brazilian female gas station attendants: two case reports," BMC Research Notes, vol. 10, no. 1, p. 52, 2017.

[28] S. C. M. A. Yahouédéhou, M. O. S. Carvalho, R. M. Oliveira et al., "Sickle cell anemia patients in use of hydroxyurea: association between polymorphisms in genes encoding metabolizing drug enzymes and laboratory parameters," Disease Markers, vol. 2018, Article ID 6105691, 11 pages, 2018.

[29] G. E. Austin, W. G. Zhao, W. Zhang, E. D. Austin, H. W. Findley, and J. J. Murtagh Jr., "Identification and characterization of the human myeloperoxidase promoter," Leukemia, vol. 9, no. 5, pp. 848-857, 1995.

[30] C. Infante-Rivard, J. K. Vermunt, and C. R. Weinberg, "Excess transmission of the NAD(P)H:quinone oxidoreductase 1 (NQO1) C609T polymorphism in families of children with acute lymphoblastic leukemia," American Journal of Epidemiology, vol. 165, no. 11, pp. 1248-1254, 2007.

[31] F. J. Piedrafita, R. B. Molander, G. Vansant, E. A. Orlova, M. Pfahl, and W. F. Reynolds, "An Alu element in the myeloperoxidase promoter contains a composite SP1-thyroid hormone-retinoic acid response element," The Journal of Biological Chemistry, vol. 271, no. 24, pp. 14412-14420, 1996.

[32] W. F. Reynolds, E. Chang, D. Douer, E. D. Ball, and V. Kanda, "An allelic association implicates myeloperoxidase in the etiology of acute promyelocytic leukemia," Blood, vol. 90, no. 7, pp. 2730-2737, 1997.

[33] E. Hallier, T. Langhof, D. Dannappel et al., "Polymorphism of glutathione conjugation of methyl bromide, ethylene oxide and dichloromethane in human blood: influence on the induction of sister chromatid exchanges (SCE) in lymphocytes," Archives of Toxicology, vol. 67, no. 3, pp. 173178, 1993. 
[34] Y. Kassogue, H. Dehbi, M. Quachouh, A. Quessar, S. Benchekroun, and S. Nadifi, "Association of glutathione Stransferase (GSTM1 and GSTT1) genes with chronic myeloid leukemia," Springerplus, vol. 4, no. 1, p. 210, 2015.

[35] G. Bhat, A. Bhat, A. Wani et al., "Polymorphic variation in glutathione-S-transferase genes and risk of chronic myeloid leukaemia in the Kashmiri population," Asian Pacific Journal of Cancer Prevention, vol. 13, no. 1, pp. 69-73, 2012. 


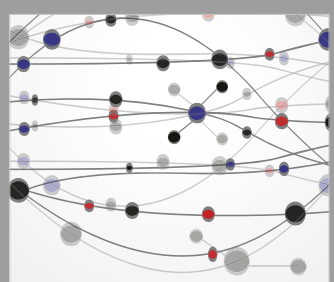

The Scientific World Journal
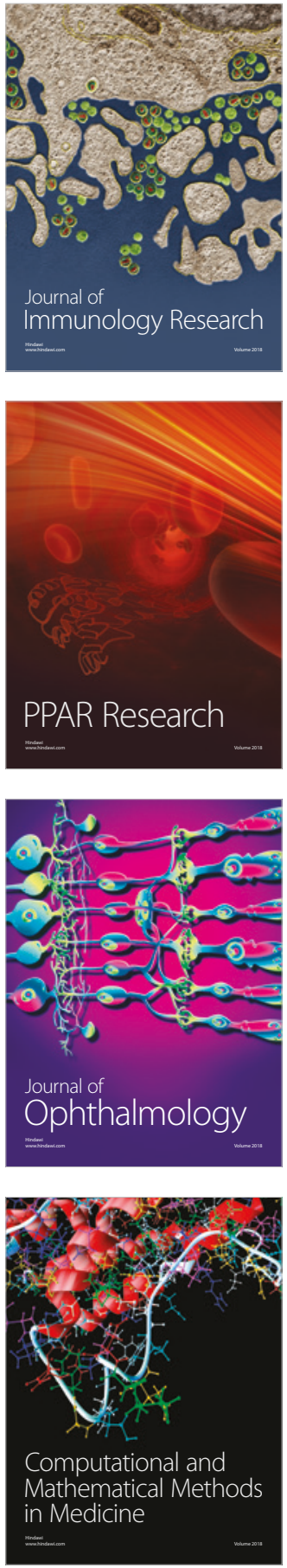

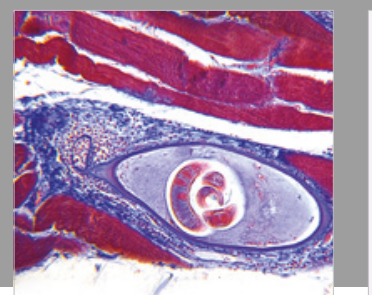

Gastroenterology Research and Practice

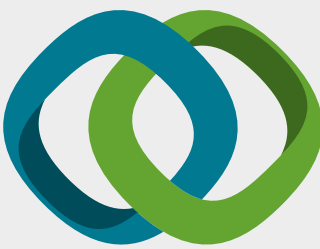

\section{Hindawi}

Submit your manuscripts at

www.hindawi.com
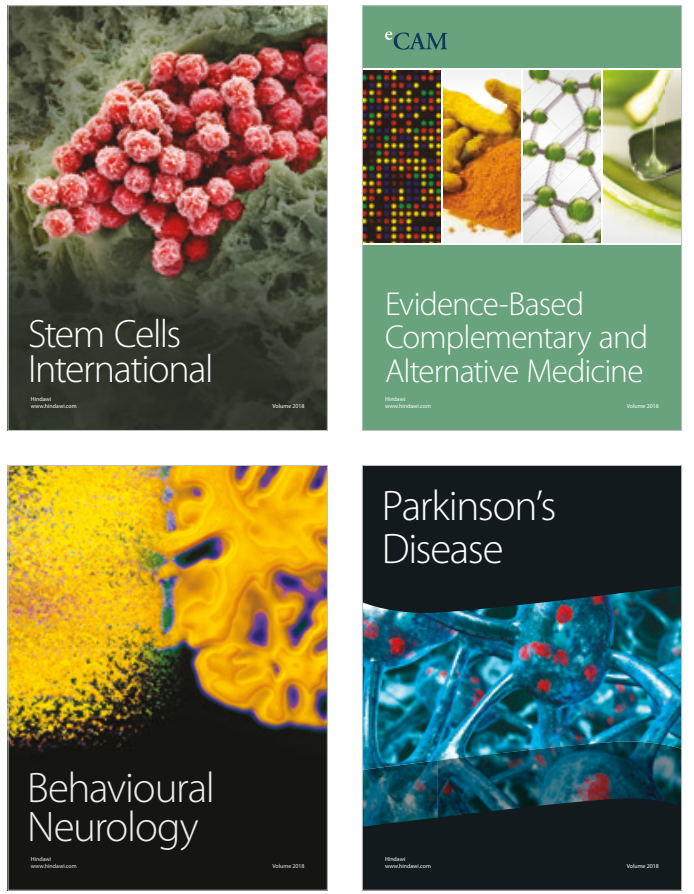

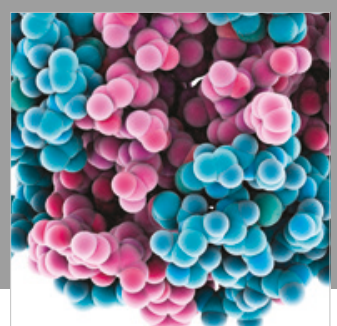

ournal of

Diabetes Research

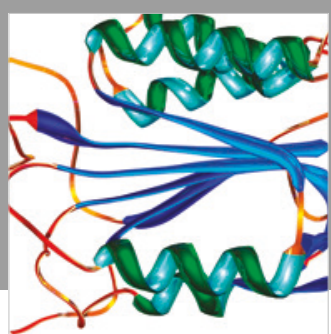

Disease Markers
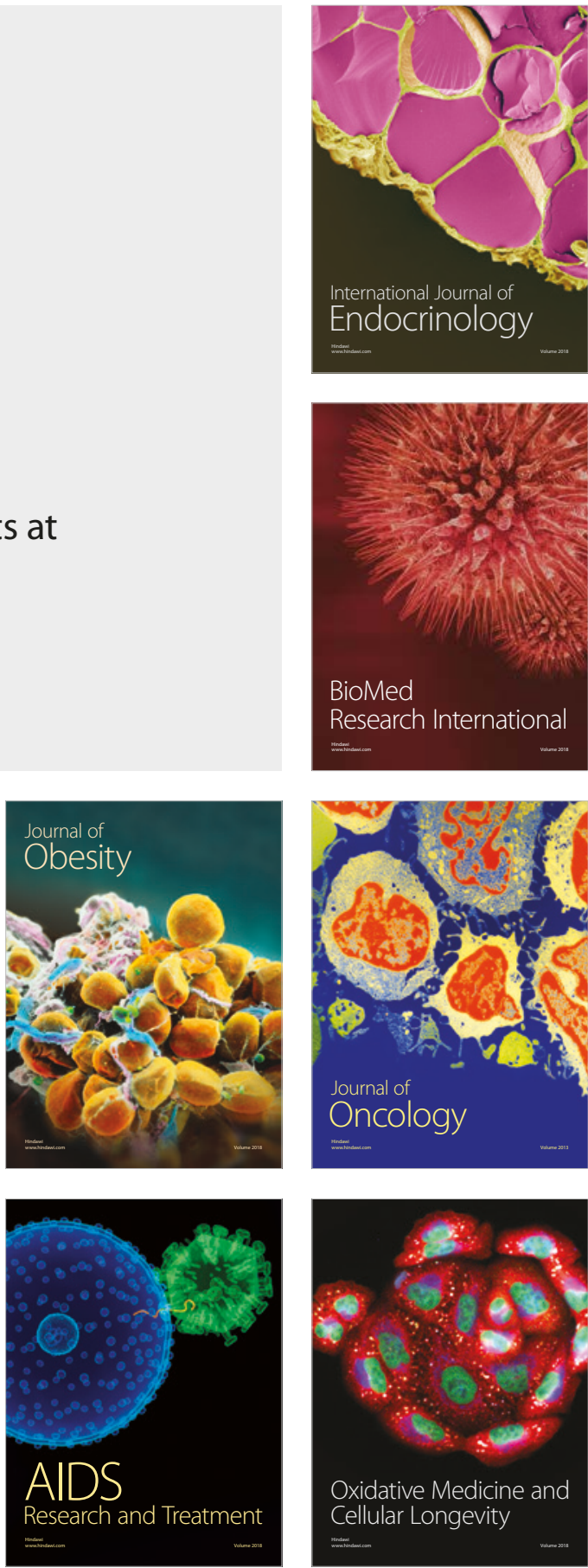